\title{
Geoglobus ahangari gen. nov., sp. nov., a novel hyperthermophilic archaeon capable of oxidizing organic acids and growing autotrophically on hydrogen with Fe(III) serving as the sole electron acceptor
}

\footnotetext{
1 Department of Microbiology, University of Massachusetts, Amherst, MA 01003, USA

2 Department of Environmental Biology, Portland State University, Portland, OR 97201, USA
}

\author{
Kazem Kashefi, ${ }^{1}$ Jason M. Tor, ${ }^{1}$ Dawn E. Holmes, ${ }^{1}$ \\ Catherine V. Gaw Van Praagh, ${ }^{1}$ Anna-Louise Reysenbach ${ }^{2}$ \\ and Derek R. Lovley ${ }^{1}$ \\ Author for correspondence: Derek Lovley. Tel: + 14135459651 . Fax: + 14135451578.
e-mail: dlovley@microbio.umass.edu
}

Keywords: Archaea, hydrothermal vents, Fe(III) reduction, long-chain fatty acids, autotrophic

\section{INTRODUCTION}

Micro-organisms with the ability to grow anaerobically with $\mathrm{Fe}$ (III) serving as the sole electron acceptor are found in both the Bacteria and the Archaea (Lovley, 2000a). Short-chain fatty acids and hydrogen

Abbreviation: AQDS, anthraquinone-2,6-disulfonate.

The GenBank/EMBL/DDBJ accession numbers for the 16S rDNA sequences of strain 234 ${ }^{\top}$, Ferroglobus placidus DSM $10642^{\top}$ and Archaeoglobus profundus DSM 5631 ${ }^{\top}$ are respectively AF220165, AF220166 and AF322392. are the primary electron donors that support the growth of mesophilic and thermophilic Fe(III)-reducing bacteria now available in pure culture (Lovley, 2000a). There has been little investigation of hyperthermophilic micro-organisms capable of using Fe(III) as an electron acceptor, even though Fe(III) is considered to be an important electron acceptor in modern hot environments such as the deep subsurface and around hydrothermal systems and may have also been an important electron acceptor on hot, early Earth and other planets (Lovley, 2000b). 
Most of the previous evaluations of Fe(III) reduction by hyperthermophiles have consisted of studies of the ability of hyperthermophiles, isolated with electron acceptors other than Fe(III), to reduce Fe(III) with hydrogen (Kashefi \& Lovley, 2000; Vargas et al., 1998). All hyperthermophiles that have been investigated to date have the ability to oxidize hydrogen with the reduction of $\mathrm{Fe}$ (III) in cell suspension (Vargas et al., 1998). Pyrobaculum islandicum in the Archaea and Thermotoga maritima in the Bacteria were found to conserve energy to support growth from hydrogen oxidation coupled to $\mathrm{Fe}(\mathrm{III})$ reduction (Kashefi \& Lovley, 2000; Vargas et al., 1998). Both of these organisms required the presence of low concentrations of yeast extract for growth on hydrogen and Fe(III). $P$. islandicum was also found to grow in medium in which peptone and yeast extract served as electron donors for $\mathrm{Fe}$ (III) reduction, but the specific compounds utilized as electron donors were not identified.

Here, we report the isolation and characterization of a novel, $\mathrm{Fe}(\mathrm{III})$-reducing hyperthermophile, designated strain $234^{\mathrm{T}}$, that was enriched and isolated from a vent sample from the Guaymas Basin using a newly developed isolation procedure in which $\mathrm{Fe}$ (III) oxide was incorporated into the solidified medium. The use of $\mathrm{Fe}$ (III) oxide as the electron acceptor for enrichment and isolation yielded a micro-organism with metabolic capabilities not previously reported for hyperthermophiles and/or Fe(III)-reducing micro-organisms. It is suggested that strain $234^{\mathrm{T}}$ be assigned to a new genus, designated Geoglobus, as Geoglobus ahangari gen. nov., sp. nov.

\section{METHODS}

Source of organism. Strain $234^{\mathrm{T}}$ was isolated from samples from a hydrothermal chimney collected by the research submersible Jason at Guaymas Basin $\left(27^{\circ} \mathrm{N}, 111^{\circ} \mathrm{W}\right.$, depth $2000 \mathrm{~m}$ ). Ferroglobus placidus DSM 10642 ${ }^{\mathrm{T}}$, Archaeoglobus fulgidus DSM 4304 ${ }^{\mathrm{T}}$, Archaeoglobus profundus DSM $5631^{\mathrm{T}}$ and Archaeoglobus veneficus DSM $11195^{\mathrm{T}}$ were obtained from the DSMZ, Braunschweig, Germany.

Enrichment of strain $234^{\top}$. Strict anaerobic culturing techniques were used throughout (Balch et al., 1979; Miller \& Wolin, 1974). Gases were passed through a column of hot copper filings to remove all traces of oxygen. All transfers and sampling of cultures were performed with syringes and needles that had been flushed with oxygen-free gas. The marine enrichment medium contained the following $\left(1^{-1}\right)$ : $\mathrm{NaCl}, 19.0 \mathrm{~g} ; \mathrm{MgCl}_{2} .6 \mathrm{H}_{2} \mathrm{O}, 9.0 \mathrm{~g} ; \mathrm{MgSO}_{4} .7 \mathrm{H}_{2} \mathrm{O}, 0.15 \mathrm{~g}$; $\mathrm{CaCl}_{2} .2 \mathrm{H}_{2} \mathrm{O}, 0.3 \mathrm{~g} ; \mathrm{KCl}, 0 \cdot 5 \mathrm{~g} ; \mathrm{KH}_{2} \mathrm{PO}_{4}, 0.42 \mathrm{~g} ;\left(\mathrm{NH}_{4}\right)_{2} \mathrm{SO}_{4}$, $0.10 \mathrm{~g}$; NaBr, 0.05 g; $\mathrm{SrCl}_{2} .6 \mathrm{H}_{2} \mathrm{O}, 0.02 \mathrm{~g}$; Difco yeast extract, $0.10 \mathrm{~g} ; \mathrm{NaHCO}_{3}, 2.5 \mathrm{~g} ; \mathrm{Na}_{2} \mathrm{SeO}_{4}, 0.02 \mathrm{~g}$. The medium was also supplemented with a vitamin mixture (Lovley \& Phillips, 1988), a trace mineral solution (Pledger \& Baross, 1989) and poorly crystalline $\mathrm{Fe}(\mathrm{III})$ oxide $\left(100 \mathrm{mmol} \mathrm{l}^{-1}\right)$, which was prepared as described previously (Lovley \& Phillips, 1986). Pyruvate (10 mM) was the electron donor for the enrichment and isolation. The medium $(10 \mathrm{ml})$ was dispensed into $26 \mathrm{ml}$ anaerobic pressure tubes (Bellco Glass, Inc.) and sparged with $\mathrm{N}_{2} / \mathrm{CO}_{2}(80: 20 \%, \mathrm{v} / \mathrm{v})$ for $12-15 \mathrm{~min}$ to remove dissolved oxygen. The tubes were then sealed with thick butyl-rubber stoppers. After autoclaving, the medium in each tube was supplemented with $0.25 \mathrm{mM}$ L-cysteine hydrochloride and $1.3 \mathrm{mM} \mathrm{FeCl}{ }_{2} .2 \mathrm{H}_{2} \mathrm{O}$ from concentrated anaerobic stock solutions. The final $\mathrm{pH}$ of the medium was approx. 6.8-7.0 (at room temperature). With $2.5 \mathrm{~g}$ sodium bicarbonate $1^{-1}(30 \mathrm{mM})$ in the growth medium at $85^{\circ} \mathrm{C}$ under a $\mathrm{N}_{2} / \mathrm{CO}_{2}(80: 20 \%, \mathrm{v} / \mathrm{v})$ atmosphere, this $\mathrm{pH}$ should be around 6.9-7.0.

Isolation of strain $234^{\top}$ on solid medium. The isolate was purified with a modification of the roll-tube method (Hungate, 1969). The solid medium was made in a two-step process. To prepare the solidifying agent, $1 \mathrm{~g}$ GELRITE gellan gum (Sigma) was added to $50 \mathrm{ml}$ anaerobic water in $128 \mathrm{ml}$ serum bottles under a $\mathrm{N}_{2}$ atmosphere. The bottles were then sealed with thick butyl-rubber stoppers. The other part of the medium, with the constituents at twice the concentration listed above and $20 \mathrm{mM}$ pyruvate, was amended with additional $\mathrm{MgCl}_{2}(20 \mathrm{mM})$ and $\mathrm{CaCl}_{2}(6 \mathrm{mM})$. This medium was then dispensed into pressure tubes in $3.5 \mathrm{ml}$ aliquots under $\mathrm{N}_{2} / \mathrm{CO}_{2}(80: 20 \%, \mathrm{v} / \mathrm{v})$. The solidifying agent and double-strength medium were autoclaved and then placed in a water bath $\left(85-90^{\circ} \mathrm{C}\right)$. After autoclaving, the solidifying-agent solution was amended with L-cysteine hydrochloride $(0.5 \mathrm{mM})$ and $\mathrm{FeCl}_{2}(2.6 \mathrm{mM})$. An inoculum $(0.7 \mathrm{ml})$ from the enrichment cultures was added anaerobically to tubes of double-concentration medium, followed immediately by an aliquot $(3.5 \mathrm{ml})$ of the solidifying agent. The contents were mixed gently and thoroughly at $85-90^{\circ} \mathrm{C}$. Next, $0.7 \mathrm{ml}$ was quickly removed and transferred into a second pressure tube containing $3.5 \mathrm{ml}$ of the doubleconcentration marine medium and mixed well. The first pressure tube was then rolled at room temperature with a tube spinner (Bellco Glass Inc.), taking care to ensure an even coating of the inner pressure tube wall. The second pressure tube was amended with the solidifying agent $(3.5 \mathrm{ml})$ and the contents were mixed as before. This and subsequent tubes were treated in the same manner as the first tube to generate serial dilutions up to a dilution of $10^{-9}$. When complete, the roll tubes were incubated vertically at $85^{\circ} \mathrm{C}$.

Evaluation of electron donors and electron acceptors utilized. In order to determine the ability of the strain to use substrates other than pyruvate, electron donors were added individually from concentrated anoxic and sterile stock solutions. Substrate utilization was monitored by measuring growth and $\mathrm{Fe}(\mathrm{II})$ production over the period of incubation at $85^{\circ} \mathrm{C}$ and under a $\mathrm{N}_{2} / \mathrm{CO}_{2}(80: 20 \%, \mathrm{v} / \mathrm{v})$ atmosphere. When hydrogen was used as the electron donor, it was provided as $\mathrm{H}_{2} / \mathrm{CO}_{2}(80: 20 \%, \mathrm{v} / \mathrm{v})$ at an overpressure of $101 \mathrm{kPa}$ and yeast extract was omitted from the medium. To evaluate the utilization of electron acceptors, poorly crystalline $\mathrm{Fe}(\mathrm{III})$ was omitted from the medium. Alternative electron acceptors were added individually from concentrated anaerobic and sterile stock solutions, using pyruvate as the electron donor at $85^{\circ} \mathrm{C}$ under a $\mathrm{N}_{2} / \mathrm{CO}_{2}(80: 20 \%$, $\mathrm{v} / \mathrm{v}$ ) atmosphere.

Temperature, $\mathrm{pH}$ and salt optima. The influence of temperature on growth was determined over the range $60-95^{\circ} \mathrm{C}$ in cultures provided with pyruvate as the electron donor and Fe(III) oxide as the electron acceptor. The cultures were incubated in either temperature-controlled hot-air incubators or water baths using a calibrated thermometer. The $\mathrm{pH}$ range for growth of strain $234^{\mathrm{T}}$ was investigated for the range $\mathrm{pH} 5 \cdot 0-8.6$ using bicarbonate buffer under a $\mathrm{N}_{2} / \mathrm{CO}_{2}$ $(80: 20 \%, v / v)$ atmosphere at $85^{\circ} \mathrm{C}$. The effect of $\mathrm{NaCl}$ on growth was determined by varying its concentration from 0 to $72 \mathrm{~g} \mathrm{l}^{-1}$. The effect of salinity was determined at $85^{\circ} \mathrm{C}$. 
Antibiotic susceptibility. To test the effect of antibiotics, a $1 \mathrm{ml}$ aliquot of an exponentially growing culture was transferred into fresh marine medium containing poorly crystalline $\mathrm{Fe}(\mathrm{III})$ oxide, pyruvate $(10 \mathrm{mM})$ and filtersterilized antibiotics. The cultures were incubated at $80{ }^{\circ} \mathrm{C}$ and routinely examined for cell growth and $\mathrm{Fe}(\mathrm{II})$ accumulation as a result of $\mathrm{Fe}(\mathrm{III})$ reduction.

Analytical techniques. Fe(III) reduction was monitored by measuring the accumulation of Fe(II) over time. The amount of $\mathrm{Fe}(\mathrm{II})$ solubilized after $2 \mathrm{~h}$ (incubation in dark and at room temperature) in anaerobic oxalate solution was determined with ferrozine as described previously (Phillips \& Lovley, 1987). Cells were counted by epifluorescence microscopy as described previously (Lovley \& Phillips, 1988). Methane was analysed with a GC (Hewlett Packard model 5890, series II) equipped with a 30-m fused silica capillary column (HP-624; Hewlett Packard) with $\mathrm{N}_{2}$ (zero grade) as the carrier gas. The oven temperature was $100^{\circ} \mathrm{C}$ and methane was determined with a flame-ionization detector.

Light and electron microscopy. Cells were routinely examined with a Zeiss Axioskop 20 phase-contrast microscope (with an oil-immersion objective $\times 100 / 1 \cdot 25$ ) equipped with a UV lamp, an LP 420 excitation filter and a BG 38 red-attenuation filter. Electron microscopy was carried out as described previously (Lovley et al., 1993).

$\mathbf{G}+\mathbf{C}$ content of the DNA. DNA isolation and determination of $\mathrm{G}+\mathrm{C}$ content were performed on $\mathrm{Fe}(\mathrm{III})$ citrate-grown cells by the Identification Service of the DSMZ. In brief, cells were first disrupted using a French pressure cell and purified on hydroxyapatite according to the procedure of Cashion et al. (1997). The DNA was digested enzymically and then dephosphorylated, the resulting deoxyribonucleosides were separated and analysed by HPLC according to Mesbah et al. (1989). Non-methylated lambda DNA (Sigma), with the $\mathrm{G}+\mathrm{C}$ content of $49.9 \mathrm{~mol} \%$, was used as the standard (Mesbah et al., 1989). The mean $\mathrm{G}+\mathrm{C}$ content $(n=3)$ was calculated from the ratio of deoxyguanosine $(\mathrm{dG})$ and deoxyadenosine (dA) according to the method of Mesbah et al. (1989).

16S rDNA sequence analysis. Cultures $(10 \mathrm{ml})$ grown with poorly crystalline $\mathrm{Fe}(\mathrm{III})$ oxide as the electron acceptor were first treated with $30 \mathrm{ml}$ filter-sterilized oxalate solution (Phillips \& Lovley, 1987) in order to remove Fe(III), which inhibits Taq polymerase. Cells were collected by centrifugation and genomic DNA was extracted as described previously (Rooney-Varga et al., 1999).

Nearly the entire $16 \mathrm{~S}$ rDNA of strain $234^{\mathrm{T}}, F$. placidus, $A$. fulgidus, $A$. profundus and $A$. veneficus was amplified with primers 25e Forward and 1525 Reverse (Achenbach \& Woese, 1995). PCR mixtures were adapted from those described previously (Murray et al., 1996). Each $100 \mu \mathrm{l}$ reaction contained $1.5 \mathrm{mM} \mathrm{MgCl}_{2}, 2.5 \mathrm{U}$ AmpliTaq (Perkin Elmer Cetus) and glycerol $(15 \%)$. There was an initial denaturation step at $92^{\circ} \mathrm{C}$ for $2 \mathrm{~min}$, followed by 30 cycles of $92{ }^{\circ} \mathrm{C}$ for $1 \mathrm{~min}, 53.5^{\circ} \mathrm{C}$ for $30 \mathrm{~s}$ and $72{ }^{\circ} \mathrm{C}$ for $1 \mathrm{~min}$ with a final extension at $72^{\circ} \mathrm{C}$ for $6 \mathrm{~min}$. PCR products were prepared for sequencing using a QIAquick PCR purification kit (Qiagen). Sequencing was performed at the University of Massachusetts Amherst Sequencing Facility.

Complete bidirectional sequences were obtained from each PCR product. Sequences were compared to sequences from the GenBank and RDP databases using BLAST (Altschul et al., 1990) and SIMILARITY_RANK (Maidak et al., 2000) algorithms. Secondary structures were verified prior to manual alignment with related $16 \mathrm{~S}$ rDNA sequences from GenBank and the RDP using the Genetic Computer Group (GCG) sequence editor (Wisconsin Package version 10). Aligned sequences were imported into PAUP 4.0b 4a (Swofford, 1998), where phylogenetic trees were inferred. The branching order was determined and compared using character-based (maximum-parsimony and maximum-likelihood) and distance-based (using the HKY85 4-parameter, Jukes-Cantor and Kimura two-parameter models) algorithms. The region considered for phylogenetic analysis, according to the conventional numbering system for $16 \mathrm{~S}$ rDNA sequence analysis, included positions $52-1480 ; 18 \%$ of the alignment, representing hypervariable regions, was masked. However, inclusion of these regions did not affect the branching order. Bootstrap analysis was performed using the distance-based HKY85 4-parameter model, with 100 replicates. In addition to the archaeal species shown in Fig. 5, representative species from the following taxonomic groups were used for construction of this phylogenetic tree: Methanococcales, Methanosarcinales, Halobacteriaceae, Methanobacteriaceae, Thermococcales, Methanopyrales and Thermoproteales.

\section{RESULTS}

\section{Enrichment and isolation}

Several of the Guaymas Basin vent samples provided active $\mathrm{Fe}(\mathrm{III})$-reducing enrichment cultures, but only the results from the enrichment known as $234^{\mathrm{T}}$ will be summarized here. Within 2 days of inoculating the $234^{\mathrm{T}}$ sample into pyruvate/Fe(III) oxide medium at $80^{\circ} \mathrm{C}$, the reddish-brown, non-magnetic $\mathrm{Fe}(\mathrm{III})$ oxide changed to a black, magnetic mineral, which was probably magnetite (Lovley et al., 1987). Inocula $(10 \%)$ from the enrichments were transferred into the same medium and incubated at $75,80,85,90$ or $100{ }^{\circ} \mathrm{C}$. The enrichment at $85^{\circ} \mathrm{C}$ was successfully transferred five times and the fifth transfer was further transferred into serial 10 -fold dilutions. The $10^{-8}$ dilution, which was the highest dilution that exhibited $\mathrm{Fe}(\mathrm{III})$ reduction, was serially diluted and the serial dilution procedure was then repeated a third time.

The highest positive dilution from the third serial transfer was used to inoculate roll tubes of pyruvate/ $\mathrm{Fe}(\mathrm{III})$ oxide medium solidified with GELRITE. After 10 days of incubation at $85^{\circ} \mathrm{C}$, well-isolated colonies $(0.5-1.0 \mathrm{~mm}$ diameter $)$ appeared in the more-dilute tubes. Individual colonies were picked from the highest positive dilutions and transferred into $2 \mathrm{ml}$ liquid medium that was amended with poorly crystalline $\mathrm{Fe}(\mathrm{III})$ oxide and pyruvate. The liquid culture with the highest rate of $\mathrm{Fe}$ (III) reduction was passed through the serial dilution procedure three more times to ensure that this was a pure culture. This isolate was designated strain $234^{\mathrm{T}}$.

\section{Morphology}

Cells of strain $234^{\mathrm{T}}$ grown with pyruvate/Fe(III) oxide were morphologically uniform (Fig. 1a). Under phasecontrast microscopy, cells of isolate $234^{\mathrm{T}}$ appeared as 

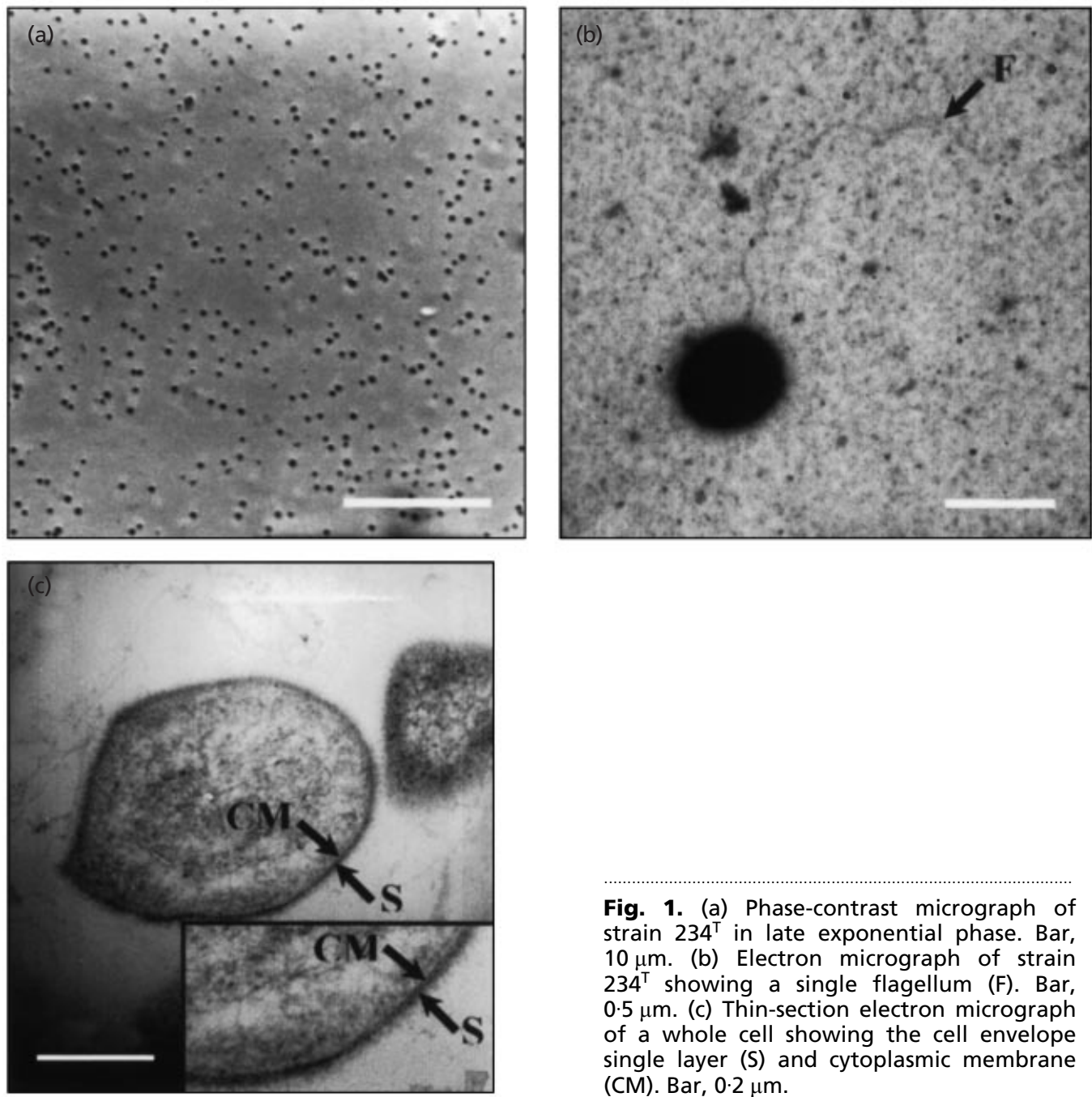

Fig. 1. (a) Phase-contrast micrograph of strain $234^{\top}$ in late exponential phase. Bar, $10 \mu \mathrm{m}$. (b) Electron micrograph of strain $234^{\top}$ showing a single flagellum (F). Bar, $0.5 \mu \mathrm{m}$. (c) Thin-section electron micrograph of a whole cell showing the cell envelope single layer (S) and cytoplasmic membrane (CM). Bar, $0.2 \mu \mathrm{m}$.
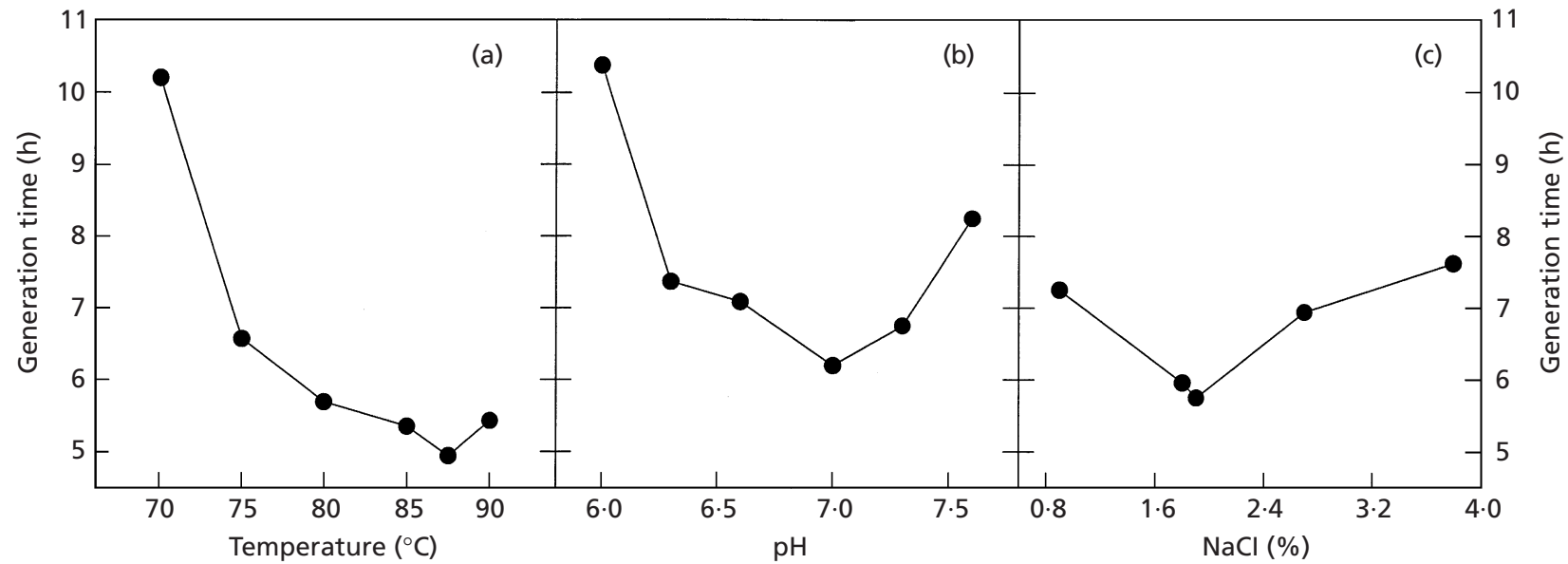

Fig. 2. Effects of temperature (a), $\mathrm{pH}(\mathrm{b})$ and $\mathrm{NaCl}$ concentration at $85^{\circ} \mathrm{C}$ (c) on growth of isolate $234^{\top}$. Doubling times were calculated from the slopes of the growth curves (not shown) at $\mathrm{pH} 7.0(\mathrm{a}, \mathrm{c})$ or at $85^{\circ} \mathrm{C}(\mathrm{b})$. All growth experiment were done with pyruvate as the electron donor and poorly crystalline $\mathrm{Fe}(\mathrm{III})$ as the electron acceptor.

regular to irregular cocci, about $0 \cdot 3-0 \cdot 5 \mu \mathrm{m}$ in diameter, usually arranged as single cells or in pairs. The cells had a single flagellum (Fig. 1b). Strain $234^{\mathrm{T}}$ was highly motile even at room temperature. When examined by phase-contrast microscopy, a tumbling motility was observed. 
Table 1. Electron donor and acceptor utilization by strain $234^{\top}$

\begin{tabular}{|c|c|}
\hline Compound & Concentration* \\
\hline \multicolumn{2}{|l|}{ Electron donors utilized } \\
\hline Hydrogen $\left(\mathrm{H}_{2} / \mathrm{CO}_{2} ; 80: 20\right)$ & $101 \mathrm{kPa}$ \\
\hline Pyruvate & 10 \\
\hline Acetate & 4 \\
\hline Malate & 10 \\
\hline Succinate & 10 \\
\hline Peptone & $0 \cdot 1 \%$ \\
\hline Formate & 10 \\
\hline Fumarate & 10 \\
\hline Yeast extract & $0 \cdot 1 \%$ \\
\hline Glycerol & 20 \\
\hline Isoleucine & $7 \cdot 6$ \\
\hline Arginine & $5 \cdot 7$ \\
\hline Serine & $9 \cdot 5$ \\
\hline Glutamine & $6 \cdot 8$ \\
\hline Asparagine & $7 \cdot 6$ \\
\hline Stearate & 1 \\
\hline Palmitate & 1 \\
\hline Valerate & $1-10$ \\
\hline Butyrate & 5 \\
\hline Propionate & 5 \\
\hline \multicolumn{2}{|l|}{ Electron donors tested but not utilized } \\
\hline Lactate & 10 \\
\hline Citrate & 10 \\
\hline Alanine & $11 \cdot 2$ \\
\hline Histidine & $6 \cdot 4$ \\
\hline Proline & $8 \cdot 7$ \\
\hline Glycine & $13 \cdot 3$ \\
\hline L-Cysteine & $8 \cdot 3$ \\
\hline Aspartic acid & $7 \cdot 5$ \\
\hline Glutamic acid & $6 \cdot 8$ \\
\hline DMSO & 2 \\
\hline Catechol & 1 \\
\hline Phenol & $0 \cdot 25-0 \cdot 50$ \\
\hline Toluene & 1 \\
\hline Benzene & $0 \cdot 5-1 \cdot 0$ \\
\hline Benzoic acid & $0 \cdot 5-1 \cdot 0$ \\
\hline $\mathrm{Fe}^{2+}$ (amorphous FeS) & 20 \\
\hline \multicolumn{2}{|l|}{ Electron acceptors utilized } \\
\hline Poorly crystalline $\mathrm{Fe}(\mathrm{III})$ oxide & $100 \mathrm{mmol} \mathrm{l}^{-1}$ \\
\hline $\mathrm{Fe}(\mathrm{III})$ citrate & 50 \\
\hline \multicolumn{2}{|l|}{ Electron acceptors not utilized } \\
\hline Oxygen & $0 \cdot 6-1$ and $20 \%$ \\
\hline $\mathrm{S}_{2} \mathrm{O}_{3}^{2-}$ & 10 \\
\hline $\mathrm{SO}_{4}^{2-}$ & $10-20$ \\
\hline $\mathrm{SO}_{3}^{2-}$ & $2-4$ \\
\hline $\mathrm{S}^{0}$ & $20 \%(\mathrm{w} / \mathrm{v})$ \\
\hline $\mathrm{NO}_{3}^{-}$ & 10 \\
\hline $\mathrm{NO}_{2}^{-}$ & $1 \cdot 0$ \\
\hline $\mathrm{MnO}_{2}$ [poorly crystalline $\left.\mathrm{Mn}(\mathrm{IV})\right]$ & 20 \\
\hline Anthraquinone-2,6-disulfonate & 5 \\
\hline Goethite & 50 \\
\hline Haematite & 50 \\
\hline
\end{tabular}

Table 1 (cont.)

\begin{tabular}{|lc|}
\hline Compound & Concentration* \\
\hline Fumarate & $10-50$ \\
DMSO & $1-2$ \\
Fe(III) pyrophosphate & 10 \\
\hline
\end{tabular}

* Concentration in $\mathrm{mM}$ unless otherwise indicated.

Transmission electron microscopy of thin sections revealed that the cell envelope is composed of a cytoplasmic membrane, a periplasmic space and a single outer surface layer, which is typical of the Archaea (Fig. 1c).

\section{Temperature, $\mathrm{pH}$ and salt optima}

With pyruvate as the electron donor and poorly crystalline $\mathrm{Fe}$ (III) oxide as the electron acceptor, strain $234^{\mathrm{T}}$ grew at between 65 and $90{ }^{\circ} \mathrm{C}$ with an optimum temperature of around $88^{\circ} \mathrm{C}$ (Fig. 2a). No growth occurred after 2 weeks of incubation at $64{ }^{\circ} \mathrm{C}$ or below or at $91{ }^{\circ} \mathrm{C}$ or above. The $\mathrm{pH}$ range for growth was $\mathrm{pH}$ $5 \cdot 0-7 \cdot 6$, with an optimum at $\mathrm{pH} 7 \cdot 0$ (generation time around $6.3 \mathrm{~h}$; Fig. $2 \mathrm{~b}$ ). The generation time at $\mathrm{pH} 5.0$ was about $12.45 \mathrm{~h}$ (not shown). No growth was detected at $\mathrm{pH} 7 \cdot 7$ or above. Strain $234^{\mathrm{T}}$ grew at $\mathrm{NaCl}$ concentrations ranging from $9 \cdot 0$ to $38 \mathrm{~g} \mathrm{l}^{-1}$, with an optimum at $19 \mathrm{~g} \mathrm{l}^{-1}$, no growth was observed at 4.5 or $72 \mathrm{~g} \mathrm{NaCl}^{-1}$ (Fig. 2c).

\section{Antibiotic sensitivity}

Growth of strain $234^{\mathrm{T}}$ was inhibited by ampicillin $\left(200 \mu \mathrm{g} \mathrm{ml}^{-1}\right)$, chloramphenicol $\left(100 \mu \mathrm{g} \mathrm{ml}^{-1}\right)$, penicillin $\mathrm{G}\left(200 \mu \mathrm{g} \mathrm{ml}^{-1}\right)$, phosphomycin $\left(200 \mu \mathrm{g} \mathrm{ml}^{-1}\right)$, rifampicin $\left(100 \mu \mathrm{g} \mathrm{ml}^{-1}\right)$ and trimethoprim $(300 \mu \mathrm{g}$ $\left.\mathrm{ml}^{-1}\right)$, but cycloheximide $\left(100 \mu \mathrm{g} \mathrm{ml}^{-1}\right)$, kanamycin $\left(200 \mu \mathrm{g} \mathrm{ml}^{-1}\right)$, neomycin sulfate $\left(100 \mu \mathrm{g} \mathrm{ml}^{-1}\right)$, novobiocin $\left(100 \mu \mathrm{g} \mathrm{ml}^{-1}\right)$, puromycin $\left(10 \mu \mathrm{g} \mathrm{ml}^{-1}\right)$ and streptomycin $\left(200 \mu \mathrm{g} \mathrm{ml}^{-1}\right)$ did not inhibit growth. Growth of strain $234^{\mathrm{T}}$ was inhibited by vancomycin hydrochloride at 100 and $200 \mu \mathrm{g} \mathrm{ml}^{-1}$ for $48 \mathrm{~h}$ and up to $72 \mathrm{~h}$, respectively, after which cells started to grow, possibly due to thermal inactivation of this compound over time.

\section{Electron donors and acceptors utilized}

Strain $234^{\mathrm{T}}$ readily grew in liquid medium at $85^{\circ} \mathrm{C}$ in which pyruvate was the sole electron donor and $\mathrm{Fe}(\mathrm{III})$ oxide was the sole electron acceptor (data not shown). There was no significant reduction of $\mathrm{Fe}(\mathrm{III})$ with pyruvate in the absence of the organism. Furthermore, there was no reduction of $\mathrm{Fe}$ (III) in control tubes that contained cells (previously grown with hydrogen as 


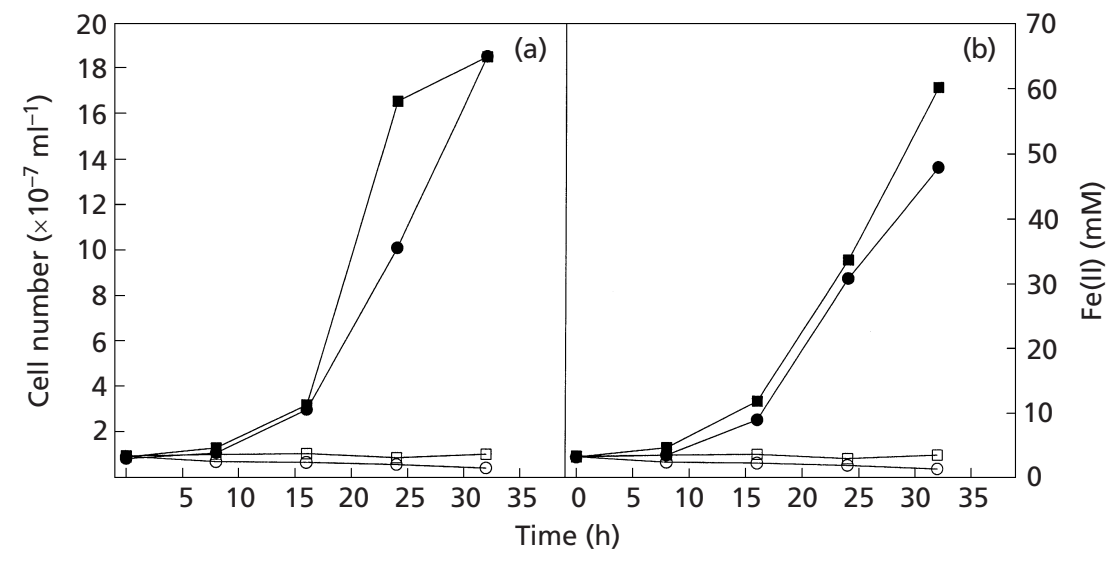

Fig. 3. Growth of strain $234^{\top}$ at $85^{\circ} \mathrm{C}$ in medium with palmitate (a) or stearate (b) as the electron donor and poorly crystalline $\mathrm{Fe}(\mathrm{III})$ as the electron acceptor. Results are means of duplicate cultures. Cell numbers (ด, O) and levels of $\mathrm{Fe}(\mathrm{II})(\boldsymbol{\square}, \square)$ are shown; open symbols denote control samples without fatty acid.

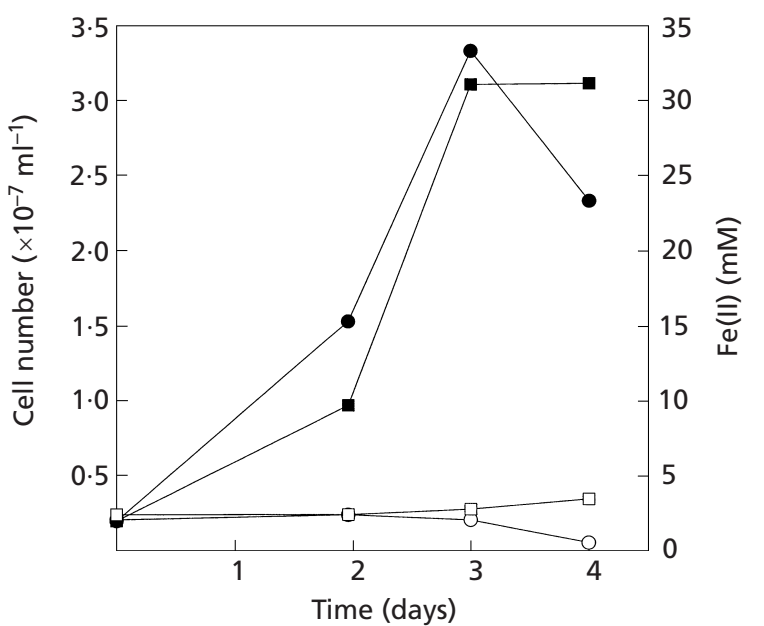

Fig. 4. Growth of strain $234^{\top}$ at $85^{\circ} \mathrm{C}$ in medium with $\mathrm{H}_{2}$ as the electron donor and poorly crystalline $\mathrm{Fe}(\mathrm{III})$ as the electron acceptor. Cell numbers $(\boldsymbol{0}, \bigcirc)$ and levels of Fe(II) $(\square, \square)$ are shown; open symbols denote control samples with $\mathrm{H}_{2}$ replaced by $\mathrm{N}_{2}$. Results are means of triplicate cultures.

electron donor) but no pyruvate and under a $\mathrm{N}_{2} / \mathrm{CO}_{2}$ $(80: 20 \%, \mathrm{v} / \mathrm{v})$ atmosphere. In addition to pyruvate, the novel isolate also grew by oxidizing acetate to carbon dioxide with the reduction of Fe(III) (Tor et al., 2001). Strain $234^{\mathrm{T}}$ could also reduce Fe(III) with a number of other organic electron donors (Table 1). Growth on sugars could not be investigated because the sugars reacted abiotically with the Fe(III) oxide at $85^{\circ} \mathrm{C}$. Several amino acids and short-chain fatty acids such as propionate, butyrate, valerate could serve as the sole electron donor for Fe(III) reduction. The longchain fatty acids palmitate (generation time $6.5 \mathrm{~h}$; Fig. $3 a)$ and stearate (generation time $7 \cdot 2$ h, Fig. 3b) also served as electron donors for $\mathrm{Fe}(\mathrm{III})$ reduction. Growth on long-chain fatty acids was more rapid than the previously reported growth on acetate (Tor et al., 2001). The addition of $0.5 \mathrm{mmol}$ palmitate resulted in the reduction of $37 \mathrm{mmol} \mathrm{Fe(III)}$ and the addition of $0.5 \mathrm{mmol}$ stearate resulted in the reduction of $44 \mathrm{mmol}$ $\mathrm{Fe}(\mathrm{III})$ in duplicate cultures. Giving the expected stoichiometry of $\mathrm{Fe}(\mathrm{III})$ reduced per mole of palmitate oxidized $(92 \mathrm{mmol})$ and based on the expected stoichiometry of $\mathrm{Fe}(\mathrm{III})$ reduced per mole of stearate oxidized (104 mmol), and also considering that a portion of the fatty acids was probably assimilated into cell carbon, the obtained stoichiometry is consistent with the oxidation of palmitate and stearate coupled to the reduction of $\mathrm{Fe}(\mathrm{III})$.

Strain $234^{\mathrm{T}}$ also grew with hydrogen as the sole electron donor for $\mathrm{Fe}(\mathrm{III})$ reduction. No organic carbon source was required for growth on hydrogen. In the presence of hydrogen, Fe(III) was reduced and $\mathrm{Fe}(\mathrm{III})$ reduction was accompanied by cell growth (Fig. 4). There was no Fe(III) reduction or cell growth in the absence of added hydrogen.

Strain $234^{\mathrm{T}}$ did not grow readily with $\mathrm{Fe}$ (III) citrate as the electron acceptor when first tested for this ability. After an extended period of time, strain $234^{\mathrm{T}}$ was adapted for growth with $\mathrm{Fe}(\mathrm{III})$ citrate, but growth and $\mathrm{Fe}$ (III) reduction remained much slower than with poorly crystalline $\mathrm{Fe}(\mathrm{III})$ oxide.

Several attempts to grow strain $234^{\mathrm{T}}$ on a wide variety of commonly considered electron acceptors [including sulfate $(10-20 \mathrm{mM})$, thiosulfate $(10 \mathrm{mM})$, sulfite $(2-4$ $\mathrm{mM}), \mathrm{S}^{0}(20 \%, \mathrm{w} / \mathrm{v})$, nitrate $(10 \mathrm{mM})$, nitrite $(1.0$ $\mathrm{mM})$ and oxygen $(0.6-1.0$ and $20 \%, \mathrm{v} / \mathrm{v})]$ other than poorly crystalline $\mathrm{Fe}$ (III) oxide (100 $\mathrm{mM})$ and $\mathrm{Fe}(\mathrm{III})$ citrate $(50 \mathrm{mM})$ using $\mathrm{H}_{2}$ (as $\mathrm{H}_{2} / \mathrm{CO}_{2}, 80: 20 \%$, v/v; $101 \mathrm{kPa})$, lactate $(10 \mathrm{mM})$, pyruvate $(10 \mathrm{mM})$, acetate $(10$ and $20 \mathrm{mM})$, yeast extract $(0.05 \%)$ and peptone $(0.1 \%)$ or a combination of $\mathrm{H}_{2} /$ lactate $(2$ and $10 \mathrm{mM})$, $\mathrm{H}_{2}$ /pyruvate (2 and $\left.10 \mathrm{mM}\right), \mathrm{H}_{2}$ /acetate (2 and $10 \mathrm{mM})$ and $\mathrm{H}_{2} /$ yeast extract $(0.02 \%)$ and peptone $(0.05 \%)$ were unsuccessful. Furthermore, no growth was observed when $\mathrm{Fe}^{2+}(20 \mathrm{mM}$ amorphous $\mathrm{FeS})$ alone or $\mathrm{Fe}^{2+}$ and $\mathrm{H}_{2}$ (as $\mathrm{H}_{2} / \mathrm{CO}_{2}, 80: 20 \%, \mathrm{v} / \mathrm{v}$; $101 \mathrm{kPa}$ ) were used as electron donors with nitrate $(10 \mathrm{mM})$ as the electron acceptor.

Similarly, attempts to grow A. fulgidus, A. profundus and $A$. veneficus on poorly crystalline $\mathrm{Fe}(\mathrm{III})$ oxide $(100 \mathrm{mM})$ or $\mathrm{Fe}(\mathrm{III})$ citrate $(20-50 \mathrm{mM})$ as an electron acceptor with $\mathrm{H}_{2}\left(\right.$ as $\mathrm{H}_{2} / \mathrm{CO}_{2}, 80: 20 \%$, v/v; $\left.101 \mathrm{kPa}\right)$, 


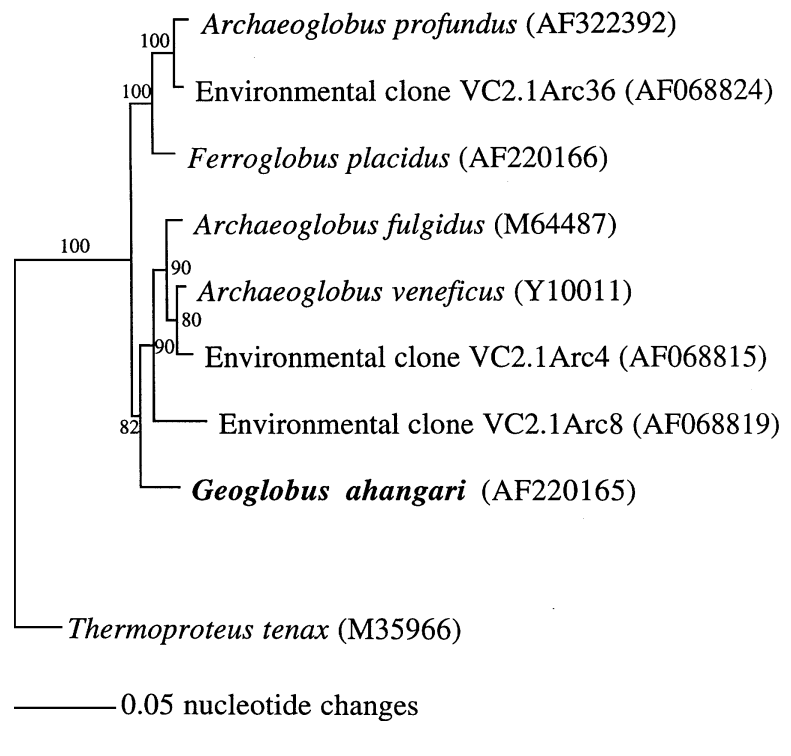

Fig. 5. Phylogenetic tree generated by maximum-likelihood analysis of $16 \mathrm{~S}$ rDNA sequences showing the relationship of strain $234^{\top}$ to previously described Archaea. Bootstrap values at nodes were calculated with 100 replicates. The branching order was identical when maximum-parsimony and distance-based algorithms were applied to aligned sequences in PAUP 4.0b $4 \mathrm{a}$ (Swofford, 1998) with hypervariable regions masked (1230 bases considered).

lactate $(10 \mathrm{mM})$, pyruvate $(10 \mathrm{mM})$, acetate $(10$ and $20 \mathrm{mM})$ or yeast extract $(0.05 \%)$ and peptone $(0.1 \%)$ or a combination of $\mathrm{H}_{2}$ /lactate $(2$ and $10 \mathrm{mM})$, $\mathrm{H}_{2}$ /pyruvate (2 and $\left.10 \mathrm{mM}\right), \mathrm{H}_{2}$ /acetate (2 and $10 \mathrm{mM})$ or $\mathrm{H}_{2} /$ yeast extract $(0.02 \%)$ and peptone $(0 \cdot 05 \%)$ were also unsuccessful.

\section{DNA base composition and phylogenetic analysis}

The $\mathrm{G}+\mathrm{C}$ content of strain $234^{\mathrm{T}}$ was $58.7 \mathrm{~mol} \%$. The aligned 16S rDNA sequences were submitted to the similarity matrix program available on the RDP website and a similarity matrix was generated with 1230 alignment positions considered. Analysis of the $16 \mathrm{~S}$ rDNA sequence of strain $234^{\mathrm{T}}$ indicated that its closest known relatives are A. fulgidus (96.2\% similar), A. profundus $(94 \cdot 1 \%)$, A. veneficus $(95 \cdot 1 \%)$ and $F$. placidus $(95 \cdot 1 \%)$, which are members of the domain Archaea (Fig. 5).

\section{Fluorescent co-factors}

Cells of strain $234^{\mathrm{T}}$ showed no fluorescence when examined under UV microscopy. In contrast, when $A$. fulgidus cells were used as controls, they showed a bluish-green fluorescence under the same conditions.

\section{Methane formation}

No methane was detected $(<0.005 \%)$ in the headspace of cultures of strain $234^{\mathrm{T}}\left(3.5 \times 10^{8}\right.$ cells ml ${ }^{-1}$ over $30 \mathrm{~h}$ incubation at $85^{\circ} \mathrm{C}$ ).

\section{DISCUSSION}

The results demonstrate that strain $234^{\mathrm{T}}$ has several unique physiological characteristics not previously demonstrated in $\mathrm{Fe}(\mathrm{III})$-reducing micro-organisms and/or hyperthermophiles. These include the ability to grow with hydrogen as the sole electron donor and $\mathrm{Fe}$ (III) oxide as the electron acceptor in the absence of an organic carbon source and the ability to use longchain fatty acids as the electron donor. As detailed below, these types of metabolism are likely to have environmental significance. Furthermore, as discussed below, the significant physiological differences between Archaeoglobus species and strain $234^{\mathrm{T}}$ indicate that these organisms should be assigned to different genera, and the differences in phylogeny and some significant differences in physiology suggest that strain $234^{\mathrm{T}}$ should not be placed in the same genus as $F$. placidus. Thus, strain $234^{\mathrm{T}}$ should be designated as the type species of a new genus.

\section{Insoluble Fe(III) oxide as an electron acceptor}

A key to the isolation of strain $234^{\mathrm{T}}$ may have been the use of insoluble $\mathrm{Fe}$ (III) oxide as the electron acceptor in the solidified isolation medium. Most Fe(III)reducing organisms, including previously described hyperthermophilic Fe(III) reducers, have been recovered in pure culture with an electron acceptor other than Fe(III) (Lovley, 2000a). In the few cases where $\mathrm{Fe}(\mathrm{III})$ has been used as the electron acceptor, soluble, chelated Fe(III) forms have been employed. The technique described here permits direct isolation of $\mathrm{Fe}$ (III)-reducing micro-organisms with $\mathrm{Fe}(\mathrm{III})$ oxide as the electron acceptor. Fe(III) oxide represents the form of $\mathrm{Fe}$ (III) that predominates in most sedimentary environments (Lovley, 1991, 2001) and the use of $\mathrm{Fe}$ (III) oxide in the isolation procedure therefore makes it possible to isolate micro-organisms that can reduce $\mathrm{Fe}(\mathrm{III})$ in its environmentally relevant form. It is not uncommon that micro-organisms isolated with soluble forms of $\mathrm{Fe}(\mathrm{III})$ are not effective in reducing insoluble $\mathrm{Fe}(\mathrm{III})$ oxide. Soluble forms of $\mathrm{Fe}(\mathrm{III})$ commonly used in the isolation of $\mathrm{Fe}$ (III)-reducing micro-organisms such as Fe(III) chelated to nitrilotriacetic acid, citrate or EDTA are toxic to some Fe(III)-reducing micro-organisms (Lovley, 2000a). Thus, the use of soluble Fe(III) forms will prevent isolation of some $\mathrm{Fe}$ (III) reducers that may be environmentally significant. For example, strain $234^{\mathrm{T}}$ grows only poorly in media in which Fe(III) citrate serves as the Fe(III) source.

Of a wide variety of electron acceptors evaluated, strain $234^{\mathrm{T}}$ grew only with $\mathrm{Fe}(\mathrm{III})$. Most of the Fe(III)reducing micro-organisms presently available in culture have the ability to use electron acceptors other than $\mathrm{Fe}(\mathrm{III})$, but this may be a function of the method by which these organisms were isolated. It is notable that strain $234^{\mathrm{T}}$, the first organism isolated directly with $\mathrm{Fe}$ (III) oxide as the electron acceptor, does not use other commonly considered electron acceptors. 
Continued isolations directly with Fe(III) oxide as the electron acceptor may indicate that there are other $\mathrm{Fe}$ (III)-reducing micro-organisms that are similarly restricted in their ability to use alternative electron acceptors. The inability of strain $234^{\mathrm{T}}$ to use the humic-substance analogue anthraquinone-2,6-disulfonate (AQDS) as an electron acceptor was unexpected, as $\mathrm{Fe}$ (III)-reducing bacteria (Lovley et al., 1996, 1998) and archaea (Lovley et al., 2000) typically have the ability to use humic substances as an electron acceptor (Lovley, 2000a).

\section{Fatty acids as electron donors}

The ability of strain $234^{\mathrm{T}}$ to oxidize a variety of fatty acids anaerobically has environmental significance. As discussed previously (Tor et al., 2001), hyperthermophiles like strain $234^{\mathrm{T}}$ that can oxidize acetate anaerobically are likely to be important in the degradation of organic matter in hot, microbial ecosystems, since acetate is a key fermentation product in these environments and acetate may also be produced via abiotic processes in nearby environments that are too hot for micro-organisms to inhabit. Long-chain fatty acids represent another component of the complex assemblage of organic matter found in many sedimentary environments. To our knowledge, strain $234^{\mathrm{T}}$ is the first hyperthermophile found to oxidize long-chain fatty acids anaerobically with any electron acceptor. The only previously described Fe(III)-reducing microorganism known to oxidize long-chain fatty acids is the mesophile Desulfuromonas palmitatus (Coates et al., 1995). Strain $234^{\mathrm{T}}$ grows much faster on long-chain fatty acids than does $D$. palmitatus. This is probably due to the fact that long-chain fatty acids are more soluble at $85^{\circ} \mathrm{C}$ than at $30^{\circ} \mathrm{C}$. While D. palmitatus grew much faster on acetate than on long-chain fatty acids, the reverse was true for strain $234^{\mathrm{T}}$.

\section{Autotrophic growth with hydrogen}

In hydrothermal environments, in which the primary source of electron donors is geothermal hydrogen, there may be little organic carbon available either as an electron donor or as a carbon source. For example, $\mathrm{Fe}(\mathrm{II})$, which is abundant in marine hydrothermal fluids, is oxidized upon exposure to aerobic seawater and the poorly crystalline $\mathrm{Fe}(\mathrm{III})$ oxides that are produced can precipitate to form $\mathrm{Fe}(\mathrm{III})$-rich, presumably organic-poor, deposits in nearby hot zones that are bathed in lower flows of geothermal, presumably hydrogen-rich, anaerobic waters (Jannasch, 1995; Karl, 1995; Pichler \& Veizer, 1999; Pichler et al., 1999). An organism such as strain $234^{\mathrm{T}}$ that can grow autotrophically on hydrogen and Fe(III) oxide should be metabolically adapted for such environments. The autotrophic growth of strain $234^{\mathrm{T}}$ on hydrogen and $\mathrm{Fe}(\mathrm{III})$ contrasts with all previously described hydrogen-oxidizing, $\mathrm{Fe}(\mathrm{III})$-reducing micro-organisms, which require a carbon source for growth on hydrogen and $\mathrm{Fe}(\mathrm{III})$. These include a diversity of mesophilic and moderately thermophilic micro-organisms (Lovley, 2000a) as well as T. maritima and P. islandicum, the two hyperthermophiles previously found to conserve energy to support growth from hydrogen oxidation coupled to $\mathrm{Fe}(\mathrm{III})$ reduction (Kashefi \& Lovley, 2000; Vargas et al., 1998).

In addition to providing a model for how microorganisms may grow on hydrogen and $\mathrm{Fe}(\mathrm{III})$ in modern hydrothermal environments, the finding that strain $234^{\mathrm{T}}$ can conserve energy to support growth without the need for an organic carbon source may have important implications for the evolution of early forms of life. It has been proposed that the protometabolism that eventually led to modern life was carried out by inorganic iron-sulfur membranes that coupled the oxidation of hydrogen to the reduction of $\mathrm{Fe}(\mathrm{III})$ (Russell et al., 1998). Geochemical models suggest that $\mathrm{Fe}(\mathrm{III})$ and hydrogen to support such a protometabolism were abundant on prebiotic Earth. For example, it has been suggested that large quantities of $\mathrm{Fe}(\mathrm{III})$ and hydrogen were produced from UV radiation hydrolysing the abundant Fe(II) in Archaean seas (Cairns-Smith et al., 1992). The geochemical literature suggests that other sources of hydrogen and $\mathrm{Fe}$ (III) are also likely to have been available on prebiotic Earth (Lovley, 2000b). Strain $234^{\mathrm{T}}$ demonstrates not only that it is possible to gain enough energy to support growth from hydrogen oxidation coupled to Fe(III) reduction, but also that enough energy can be derived from this form of respiration to provide the cell's entire requirement for organic carbon from carbon dioxide fixation. Such carbon fixation could have been important in the evolution of Fe(III) reduction from an inorganic- to an organic-based life form.

\section{Placement of strain $234^{\top}$ in a new genus, Geoglobus gen. nov.}

The 16S rDNA sequence of strain $234^{\mathrm{T}}$ indicates that it is most closely related to species of Archaeoglobus and Ferroglobus, but different enough to warrant the establishment of a new genus if the phenotype is also significantly different. Archaeoglobus and Ferroglobus species have been placed in separate genera even though they are similar in morphology and temperature and salinity optima, and both have fluorescent cofactors. The primary justification for placing $F$. placi$d u s$ in a genus separate from Archaeoglobus species appears to be the differences in the form of respiration that these organisms use to conserve energy to support growth (Hafenbradl et al., 1996). F. placidus has been shown to grow with $\mathrm{Fe}(\mathrm{II})$ or sulfide as the electron donor and nitrate as the electron acceptor (Hafenbradl et al., 1996). It can also grow with hydrogen as the electron donor and sulfite as the electron acceptor (Hafenbradl et al., 1996). In contrast, Archaeoglobus species do not use nitrate as an electron acceptor, but reduce sulfate, thiosulfate or sulfite with organic electron donors or hydrogen (Huber et al., 1997; Stetter, 1988; Stetter et al., 1987). 
Although analysis of its $16 \mathrm{~S}$ rDNA sequence suggests that strain $234^{\mathrm{T}}$ is most closely related to Archaeoglobus species, its respiratory mode is completely different. Unlike the Archaeoglobus species, strain $234^{\mathrm{T}}$ is unable to use sulfur forms as electron acceptors, it lacks a dissimilatory sulfite reductase (a property shared by all Archaeoglobus species) and it grows exclusively with $\mathrm{Fe}(\mathrm{III})$ oxide as the electron acceptor. Cell suspensions of $A$. fulgidus reduced $\mathrm{Fe}$ (III) with hydrogen as the electron donor (Vargas et al., 1998), but attempts to grow this organism or A profundus or A. veneficus with hydrogen or organic electron donors and $\mathrm{Fe}$ (III) as the electron acceptor have been unsuccessful. Another indication of the differences in modes of respiration between strain $234^{\mathrm{T}}$ and Archaeoglobus species is the finding that both $A$. fulgidus and $A$. profundus possess $c$-type cytochromes that resemble the Desulfovibrio $c_{3}$ cytochromes in spectral properties and molecular mass (K. Kashefi and P. L. Hartzell, unpublished results), whereas strain $234^{\mathrm{T}}$ lacks $c$-type cytochromes (S. Childers, personal communication). In contrast to $A$. fulgidus and $A$. veneficus, which produce small amounts of methane during growth (Huber et al., 1997; Stetter, 1988; Zellner et al., 1989), no methane was detected in cultures of strain $234^{\mathrm{T}}$.

In a similar manner, although it has been recognized recently that $F$. placidus can reduce Fe(III) (Tor et al., 2001), strain $234^{\mathrm{T}}$ does not have the hallmark respiratory characteristic of $F$. placidus, the ability to oxidize Fe(II) with the reduction of nitrate. Furthermore, strain $234^{\mathrm{T}}$ lacks the fluorescent co-factors found not only in $F$. placidus, but also in A. fulgidus, $A$. profundus and $A$. veneficus (Hafenbradl et al., 1996; Huber et al., 1997; Stetter, 1988; Zellner et al., 1989). Finally, the 16S rDNA sequence similarity of isolate $234^{\mathrm{T}}$ to $F$. placidus is $95 \cdot 1 \%$ (1230 alignment positions considered). Under current taxonomic practice, an evolutionary distance in this range is considered justification for the establishment of a new genus. Just as the criteria for differences in mode of respiration justify the separation of Archaeoglobus and Ferroglobus species into separate genera, equally significant respiratory differences warrant the placement of strain $234^{\mathrm{T}}$ in a genus separate from Archaeoglobus and Ferroglobus. The name Geoglobus ahangari gen. nov., sp. nov. is proposed.

\section{Description of Geoglobus gen. nov.}

Geoglobus (Ge.o.glo'bus. Gr. n. Ge the Earth; L. masc. n. globus ball; N.L. masc. n. Geoglobus a ball from the Earth).

Cells are regular to irregular, lobe-shaped cocci, $0 \cdot 3-0.5 \mu \mathrm{m}$ in diameter, occurring singly or in pairs. Motile by a monopolar flagellum. Strictly anaerobic chemo-organotrophs that grow by oxidizing acetate, pyruvate, palmitate and stearate coupled to reduction of $\mathrm{Fe}(\mathrm{III})$. Can also grow autotrophically with $\mathrm{H}_{2}$ as the electron donor and poorly crystalline Fe(III) oxide as the electron acceptor. Reduction of poorly crys- talline $\mathrm{Fe}$ (III) oxide results in the accumulation of what appears to be extracellular, ultrafine-grained magnetite. $\mathrm{G}+\mathrm{C}$ content of the DNA of the type species is $58.7 \mathrm{~mol} \%$. The type species is Geoglobus ahangari.

\section{Description of Geoglobus ahangari sp. nov.}

Geoglobus ahangari [a.han.ga'ri. N.L. n. ahangari from Farsi masc. n. ahangar a blacksmith or a smith who works with iron, named after Kaveh Ahangar, the mythical Persian hero who was also a blacksmith by trade; arbitrary name referring to the ability to use $\mathrm{Fe}(\mathrm{III})$ as an electron acceptor].

The type strain was enriched from a deep-sea hydrothermal vent (chimney) sample from Guaymas Basin, Gulf of California (at a depth of $2000 \mathrm{~m}$ ) with pyruvate as the electron donor and poorly crystalline Fe(III) oxide as the electron acceptor. Grows by oxidizing $\mathrm{H}_{2}$, acetate, pyruvate, succinate, fumarate, formate, malate, glycerol, methanol, ethanol, yeast extract, peptone, isoleucine, aspartic acid, glutamic acid, arginine, L-cysteine, serine, glutamine, asparagine, propionate, butyrate, valerate, palmitate or stearate coupled to the reduction of $\mathrm{Fe}(\mathrm{III})$. Only poorly crystalline $\mathrm{Fe}$ (III) oxide and $\mathrm{Fe}$ (III) citrate are used as electron acceptors. Other electron acceptors such as $\mathrm{S}_{2} \mathrm{O}_{3}^{2-}, \mathrm{SO}_{4}^{2-}, \mathrm{SO}_{3}^{2-}, \mathrm{S}^{0}, \mathrm{NO}_{3}^{-}, \mathrm{NO}_{2}^{-}, \mathrm{O}_{2}, \mathrm{Mn}(\mathrm{IV})$, AQDS, malate and fumarate are not utilized as electron acceptors (Table 1). Growth occurs at temperatures between 65 and $90^{\circ} \mathrm{C}$ (optimum temperature, approximately $88^{\circ} \mathrm{C}$ ), in the presence of $\mathrm{NaCl}$ concentrations of 9.0-38.0 $\mathrm{g} \mathrm{l}^{-1}$ (optimum $19 \mathrm{~g} \mathrm{NaCl} \mathrm{l}^{-1}$ ) and at near-neutral $\mathrm{pH}(\mathrm{pH} \mathrm{6} 8-7 \cdot 0)$. Sensitive to ampicillin, chloramphenicol, penicillin $\mathrm{G}$, phosphomycin, rifampicin and trimethoprim, but resistant to cycloheximide, kanamycin, neomycin sulfate, novobiocin, puromycin, streptomycin and vancomycin hydrochloride.

The type strain is strain $234^{\mathrm{T}}$ (= ATCC BAA- $425^{\mathrm{T}}$ ). The 16S rDNA sequence has been deposited in GenBank under accession number AF220165.

\section{ACKNOWLEDGEMENTS}

We thank Lucy Ru-Sin Yin for support with electron microscopy. This research was supported by grant MCB0085365 from the LExEn program of the National Science Foundation.

\section{REFERENCES}

Achenbach, L. \& Woese, C. (1995). 16S and 23S rRNA-like primers. In Archaea: a Laboratory Manual, pp. 201-203. Edited by F. T. Robb, A. R. Place, K. R. Sowers, H. J. Schreier, S. DasSarma \& E. M. Fleischmann. Cold Spring Harbor, NY: Cold Spring Harbor Laboratory.

Altschul, S. F., Gish, W., Miller, W., Myers, E. W. \& Lipman, D. J. (1990). Basic local alignment search tool. J Mol Biol 215, 403-410.

Balch, W. E., Fox, G. E., Magrum, L. J., Woese, C. R. \& Wolfe, R. S. (1979). Methanogens: re-evaluation of a unique biological group. Microbiol Rev 43, 260-296. 
Cairns-Smith, A. G., Hall, A. J. \& Russell, M. J. (1992). Mineral theories of the origin of life and an iron sulfide example. Origins Life Evol Biosphere 22, 161-180.

Cashion, P., Holder-Franklin, M. A., McCully, J. \& Franklin, M. (1997). A rapid method for the base ratio determination of bacterial DNA. Anal Biochem 81, 461-466.

Coates, J. D., Lonergan, D. J., Phillips, E. J. P., Jenter, H. \& Lovley, D. R. (1995). Desulfuromonas palmitatis sp. nov., a marine dissimilatory $\mathrm{Fe}$ (III) reducer that can oxidize long-chain fatty acids. Arch Microbiol 164, 406-413.

Hafenbradl, D., Keller, M., Dirmeier, R., Rachel, R., Roßnagel, P., Burggraf, S., Huber, H. \& Stetter, K. O. (1996). Ferroglobus placidus gen. nov., sp. nov., a novel hyperthermophilic archaeum that oxidizes $\mathrm{Fe}^{2+}$ at neutral $\mathrm{pH}$ under anoxic conditions. Arch Microbiol 166, 308-314.

Huber, H., Jannasch, H., Rachel, R., Fuchs, T. \& Stetter, K. O. (1997). Archaeoglobus veneficus sp. nov., a novel facultative chemolithoautotrophic hyperthermophilic sulfite reducer, isolated from abyssal black smokers. Syst Appl Microbiol 20, 374-380.

Hungate, R. E. (1969). A roll tube method for cultivation of strict anaerobes. Methods Microbiol 3B, 117-132.

Jannasch, H. W. (1995). Microbial interactions with hydrothermal fluids. Geophys Monogr 91, 273-296.

Karl, D. M. (1995). Ecology of free-living hydrothermal vent microbial communities. In The Microbiology of Deep-Sea Hydrothermal Vents, pp. 35-124. Edited by D. M. Karl. New York: CRC Press.

Kashefi, K. \& Lovley, D. R. (2000). Reduction of Fe(III), Mn(IV), and toxic metals at $100{ }^{\circ} \mathrm{C}$ by Pyrobaculum islandicum. Appl Environ Microbiol 66, 1050-1056.

Lovley, D. R. (1991). Dissimilatory Fe(III) and Mn(IV) reduction. Microbiol Rev 55, 259-287.

Lovley, D. R. (2000a). Dissimilatory Fe(III)- and Mn(IV)-reducing prokaryotes. In The Prokaryotes (www.prokaryotes.com). Edited by M. Dworkin, S. Falkow, E. Rosenberg, K.-H. Schleifer \& E. Stackebrandt. http://link.springer-ny.com/link/service/books/10125/ papers/1003001/10030279.htm

Lovley, D. R. (2000b). Fe(III) and Mn(IV) reduction. In Environmental Microbe-Metal Interactions, pp. 3-30. Edited by D. R. Lovley. Washington, DC: American Society for Microbiology.

Lovley, D. R. (2001). Reduction of iron and humics in subsurface environments. In Subsurface Microbiology and Biogeochemistry, pp. 193-217. Edited by J. K. Fredrickson \& M. K. Fletcher. New York Wiley.

Lovley, D. R. \& Phillips, E. J. P. (1986). Organic matter mineralization with reduction of ferric iron in anaerobic sediments. Appl Environ Microbiol 51, 683-689.

Lovley, D. R. \& Phillips, E. J. P. (1988). Novel mode of microbial energy metabolism: organic carbon oxidation coupled to dissimilatory reduction of iron or manganese. Appl Environ Microbiol 54, 1472-1480.

Lovley, D. R., Stolz, J. F., Nord, G. L. \& Phillips, E. J. P. (1987). Anaerobic production of magnetite by a dissimilatory iron-reducing microorganism. Nature 330, 252-254.

Lovley, D. R., Giovannoni, S. J., White, D. C., Champine, J. E., Phillips, E. J.P., Gorby, Y. A. \& Goodwin, S. (1993). Geobacter metallireducens gen. nov. sp. nov., a microorganism capable of coupling the complete oxidation of organic compounds to the reduction of iron and other metals. Arch Microbiol 159, 336-344.

Lovley, D. R., Coates, J. D., Blunt-Harris, E. L., Phillips, E. J. P. \& Woodward, J. C. (1996). Humic substances as electron acceptors for microbial respiration. Nature 382, 445-448.
Lovley, D. R., Fraga, J. L., Blunt-Harris, E. L., Hayes, L. A., Phillips, E. J. P. \& Coates, J. D. (1998). Humic substances as a mediator for microbially catalyzed metal reduction. Acta Hydrochim Hydrobiol 26, 152-157.

Lovley, D. R., Kashefi, K., Vargas, M., Tor, J. M. \& Blunt-Harris, E. L. (2000). Reduction of humic substances and Fe(III) by hyperthermophilic microorganisms. Chem Geol 169, 289-298.

Maidak, B. L., Cole, J. R., Lilburn, T. G. \& 9 other authors (2000). The RDP (Ribosomal Database Project) continues. Nucleic Acids Res 28, 173-174.

Mesbah, M., Premachandran, U. \& Whitman, W. B. (1989). Precise measurement of the $\mathrm{G}+\mathrm{C}$ content of deoxyribonucleic acid by highperformance liquid chromatography. Int J Syst Bacteriol 39, 159-167.

Miller, T. L. \& Wolin, M. J. (1974). A serum bottle modification of the Hungate technique for cultivating obligate anaerobes. Appl Microbiol 27, 985-987.

Murray, A. E., Hollibaugh, J. T. \& Orrego, C. (1996). Phylogenetic compositions of bacterioplankton from two California estuaries compared by denaturing gradient gel electrophoresis of $16 \mathrm{~S}$ rDNA fragments. Appl Environ Microbiol 62, 2676-2680.

Phillips, E. J. P. \& Lovley, D. R. (1987). Determination of Fe(III) and $\mathrm{Fe}(\mathrm{II})$ in oxalate extracts of sediment. Soil Sci Soc Am J 51, 938-941.

Pichler, T. \& Veizer, J. (1999). Precipitation of Fe(III) oxyhydroxide deposits from shallow-water hydrothermal fluids in Tutum Bay, Ambitle Island, Papua New Guinea. Chem Geol 162, 15-31.

Pichler, T., Veizer, J. \& Hall, G. E. M. (1999). Natural input of arsenic into a coral-reef ecosystem by hydrothermal fluids and its removal by Fe(III) oxyhydroxides. Environ Sci Technol 33, 1373-1378

Pledger, R. J. \& Baross, J. A. (1989). Characterization of an extremely thermophilic archaebacterium isolated from a black smoker polychaete (Paralvinella sp.) at the Juan de Fuca Ridge. Syst Appl Microbiol 12, 249-256.

Rooney-Varga, J. N., Anderson, R. T., Fraga, J. L., Ringelberg, D. \& Lovley, D. R. (1999). Microbial communities associated with anaerobic benzene degradation in a petroleum-contaminated aquifer. Appl Environ Microbiol 65, 3056-3063.

Russell, M. J., Daia, D. E. \& Hall, A. J. (1998). The emergence of life from $\mathrm{FeS}$ bubbles at alkaline hot springs in an acid ocean. In Thermophiles: the Keys to Molecular Evolution and the Origin of Life?, pp. 77-126. Edited by J. Wiegel \& M. W. W. Adams. Philadelphia: Taylor \& Francis.

Stetter, K. O. (1988). Archaeoglobus fulgidus gen. nov., sp. nov. : a new taxon of extremely thermophilic Archaebacteria. Syst Appl Microbiol 10, 172-173.

Stetter, K. O., Lauerer, G., Thomm, M. \& Neuner, A. (1987). Isolation of extremely thermophilic sulfate reducers: evidence for a novel branch of archaebacteria. Science 236, 822-824.

Swofford, D. L. (1998). PAUP*. Phylogenetic analysis using parsimony (*and other methods). Sunderland, MA: Sinauer Associates.

Tor, J. M., Kashefi, K. \& Lovley, D. R. (2001). Acetate oxidation coupled to $\mathrm{Fe}(\mathrm{III})$ reduction in hyperthermophilic microorganisms. Appl Environ Microbiol 67, 1363-1365.

Vargas, M., Kashefi, K., Blunt-Harris, E. L. \& Lovley, D. R. (1998). Microbiological evidence for Fe(III) reduction on early Earth. Nature 395, 65-67.

Zellner, G., Stackebrandt, E., Kneifel, H., Messner, P., Sleytr, U. B., Conway De Macario, E., Zabel, H. P., Stetter, K. O. \& Winter, J. (1989). Isolation and characterization of a thermophilic, sulfate reducing Archaebacterium, Archaeoglobus fulgidus strain Z. Syst Appl Microbiol 11, 151-160. 